\title{
Peran Guru Bimbingan dan Konseling dalam Penanganan Kasus Kesulitan Menulis pada Siswa
}

\author{
Rizka Lailatul Ramadhani ${ }^{{ }^{*}}$, Yeni Karneli ${ }^{2}$ \\ Universitas Negeri Padang ${ }^{12}$ \\ *) Correspondence Author, e-mail: rizkalailatu103@gmail.com
}

\begin{abstract}
Abstrak: Kesulitan belajar menulis nama lain dari disgrafia. Disgrafia menunjuk adanya suatu ketidakmampuan peserta didik mengingat cara membuat huruf atau simbolsimbol yang berbentuk angka dalam matematika. Disgrafia sering dikaitkan dengan dysleksia (kesulitan membaca) karena masih dalam kategori kesulitan belajar. Gangguan menulis atau kesulitan belajar menulis terdapat beberapa faktor diantaranya yaitu, terganggunya motorik pada anak, perilaku ketika menulis, persepsi, ingatan, penggunaan tangan yang dominan, kemampuan cross modal, serta kemampuan memahami instruksi.Adanya program bimbingan dan konseling ini guru BK dapat memberikan solusi-solusi yang telah diuraian di atas terhadap keslitan belajar yang di alami siswa terkhusus pada siswa yang kesulitan dalam hal menulis.
\end{abstract}

Kata Kunci: Kesulitan Menulis, Bimbingan dan Konseling

Article History: Received on 09/09/2020; Revised on 10/10/2020; Accepted on 13/11/2020; Published Online: 29/12/2020.

Sumber daya manusia (SDM) Salah satu untuk memajukan sebuah bangsa yang handal dan bermutu.Saat ini orang lebih memnetingkan SDM yang bermutu dan pada SDA yang berlimpah tetapi tidak mampu untuk mengolahnya.Untuk mencapai SDM yang bermutu perlunya kekuatan yang optimal dengan upaya-upaya yang serius dan sungguh-sungguh dari segenap masyarakat yang ada di bangsa tersebut. SDM yang bermutu hanya dapat di wujudkan dari pendidikan yang bermutu juga.Oleh karena itu, upaya peningkatan pendidikan yang bermutu merupakan titik akhir atau harga mati dalam menuju SDM yang bermutu atau berkualitas.Salah satu SDM yang dapat menjadi sebuah hal yang berkualitas adalah dengan adanya literatur yang baik adari SDM tersebut. Artinya, keterampilan literasi (membaca dan menulis) yang dimiliki haruslah lebih mendominasidaripada keterampilan orasinya (menyimak danberbicara) (Kharizmi,2019).

Menulis tidak hanya menyalin tetapi juga menuangkan pikiran dan perasaan ke dalam bentuk pola- pola tulisan.Hal yang didapat dari kepandaian anak dalam menulis yaitu mengajarkan anak untuk mandiir, seepri, mencatat sendiri, menyalin, dan dapat membaca tulisan yang ia tulis sendiri. Menulis merupakan sebuah kegiatan yang dimana seseorang tersebut dituntut untuk menghasilkan sebuah karya tulis yang dapat dbaca oleh setiap orang.Tanpa adanya kemampuan untuk menulis makaseseorang akan sulit 
dalam segi belajar lainnya. Menulis harus diberikan pengajaran pada anak saat mulai masuk SD, karena menulis mempunyai peranan penting dalam kehidupan sehari - hari di antarannya : menulis merupakan tempat dasar untuk mengespresikan diri, menulis digunakan untuk berbagi informasi apapun itu kepada pembaca, melengkapi kewajiban, dan sarana untuk mencari pekerjaan. Akan tetapi kenyataan yang ada dilapangan , anak saat masuk SD sebagian besar masih mengalami kesulitan menulis. Hal ini akan berdampak pada anak yang dapat menghambat dalam proses belajar,berbahasa, dan berkomunikasi dengan sekelilingnya.

Disgrafia merupakan kesulitan khusus anak - anak yang tidak bisa menuliskan atau mengekspresikan pikirannya kedalam bentuk tulisan, tidak bisa karena mereka tidak mampu menyusun kata dengan baik dan mengkoordinasikan motorik halusnya (tangan) untuk menulis .umumnya ksulitan menulis terjadi pada saat anak baru belajar menulis.

Gangguan pada proses menulis dan dapat menyebabkan masalah dalam mengeja, bentuk tulisan tangan yang buruk, dan dalam menuangkan ide keatas kertas. Disgrafia mencakup menulis permulaan, mengeja, menulis ekspresif. Menulis ekspresif atau mengarang adalah mengungkapkan pikiran atau perasaan ke dalam suatu bentuk tulisan, sehingga dapat dipahami oleh orang lain yang sebahasa (Mulyati, 2012) .

\section{HASIL DAN DISKUSI}

\section{Menulis}

Menurut Sujanto dalam (Yarni,2018), kegiatan menulis merupakan proses dalam perkembangan keterampilan anak dalam berbahasa. Menulis bukan hanya berkaitan dengan penggunaan tata bahasa dan tanda baca saja, melainkan sebuah proses yang dapat mengembangkan kemampuan atau keterampilan dalam berpikir dinamis dan efektif. Keterampilan menulis menjadihal yang sangat penting untuk dimiliki oleh setiap manusia, sebagai modal utama meraih kesuksesan dimasa yang akan datang. Seseorang yang terampil menulis perlu latihan yang relative lama dan cenderung dilakukan secara berulang-ulang. Hal ini dikarenakan keterampilan menulis merupakan suatuproses pertumbuhan dan perkembangan melalui banyak latihan.

Menulis bukan hanya sebagai symbol dari sutau kegiatan, tetapi menulis dapat sebagai informasi dari pengetahuan yang didapat dan dituangkan melalui tulisan.Kemampuan menulis pada anak dapat meningkatkan rasa percaya diri dan membantu memunculkan kreativitas pada anak.Akan tetapi, kenyataannya kemampuan berbahasa pada siswa SD belum sesuai dengan yang diharapkan.Hal ini diketahui masih banyaknya kesalahan siswa dalam berbahasa terutama dalam hal menulis karangan.Kesalahan tersebut dapat dilihat pada penggu- naan ejaan, diksi, kalimat efektif, dan pengembangan paragraf.

Pada hakikatnya, menulis adalah bentuk peluapan sesuatu dengan menggunakan bahasa secara tertulis Karsana (didalam Yarni, 2018).Cere ( didalam Yarnim 2018) menyatakan menulis merupakan komunikasi. Selanjutnya dikatakan bahwa di dalam komunikasi terdapat empat unsur, yaitu menulis merupakan (1) bentuk ekspresi diri; (2) sesuatu yang umum disampaikan ke pembaca; (3) aturan dan tingkah laku; serta (4) 
menulis merupakan sebuah cara belajar. Sebagai bentuk dari ekspresi diri, menulis bertujuan untuk mengkomunikasikan, men- yampaikan sebuah ide dan pokok pikiran melewati batas waktu dan ruang yang tak ditentukan. Artinya, menulis dapat dilakukan oleh siapa saja , kapan saja dan dimana sja, tergantung keadaaan si penulis.

Avelrod dan Cooper (didalam Yarni, 2018) menyatakan bahwa menulis merupakan suatu proses penemuan yang penuh dan membuat seseorang dapat belajar mengatur dan menghargai waktu. Seseorang yang mampu menulis dengan baik, maka ia tentu sudah terlatih dari sebelumnya. Sedangkan di sisi lain, Akhadiah (didalam Yarni, 2018) mengemukakan bahwa menulis merupakan kemampuan utuhyang menuntut sejumlah pengetahuan dan keterampilan seseorang.

\section{Karakteristik Anak Yang Mengalami Gangguan Menulis}

Anak-anak yang mengalami disgrafia akan memunculkan beberapa gejala atau ciriciri yang dapat mengidentifikasi gangguan tersebut. Kendell dan Stefanyshyn (2012), merincinya sebagai berikut: (1)Terdapat ketidakkonsistenan bentuk huruf dalam tulisannya saat menulis, (2)Penggunaan huruf besar dan huruf kecil masih tercampur. (3)Ukuran dan bentuk huruf dalam tulisannya tidak proporsional. (4)Anak tampak harus berusaha keras saat mengomunikasikan suatu ide, pengetahuan, atau pemahamannya lewat tulisan. (5)Sulit memegang bolpoin maupun pensil dengan mantap. (6)Berbicara pada diri sendiri ketika sedang menulis, atau malah terlalu memperhatikan tangan yang dipakai untuk menulis. (7)Cara menulis tidak konsisten, tidak mengikuti alur garis yang tepat dan proporsional. (8)tetap mengalami kesulitan meskipun hanya diminta menyalin contoh tulisan yangsudah ada.

Dari gejala yang sudah di uraikan di atas guru maupun konselor sekolah harus mampu mendeteksi sedini mungkin gangguan yang dimiliki oleh anak agar dapat di entaskan dengan sesegera mungkin dengan pemberian layanan ata bantuan kepada anak tersebut, serta juga dapat mengadakan pengamatan dengan dilakukannya pengamatan atau asesmen, untuk mengenali gangguan yang ada pada anak, jika asesmen sudah dilakukan, kemudian guru dapat merencanakan strategi belajar menulis yang sesuai dengan tingkat atau jenis hambatan yang ada pada anak disgrafia tersebut (Suhartono, 2016).

\section{Faktor-Faktor Kesulitan Menulis}

Kesulitan membaca, menulis dan berhitung dapat dipengaruhi oleh beberapa faktor yaitu faktor internal dan faktor eksternal.Faktor internal terjadi dari aspek psikologis yaitu kesehatan fisik dari siswa, fisik yang lemah juga dapat mempengaruhi proses belajar siswa, selain itu peran fisiologis pada tubuh siswa yang sangat mempengaruhi yaitu panca indera. Sedangkan faktor eksternal terjadi dari lingkungan sosial.Lingkungan sosial siswa, keluarga bahkan lingkungan sekitar siswa. Faktor lingkungan keluarga yang mempengaruhi kesulitan membaca, menulis dan berhitung mencakup latar belakang keluarga, cara memberikan pola asuh anak dirumah dan perlakukan anak di rumah.

Anak yang didampingi oleh orangtua saat belajar dirumah akan memiliki persentase yang lebih rendah dari pada anak yang tidak didampingi, karena orang tua ikut serta dalam proses perkembangan siswa saat belajar di rumah, selain itu anak yang 
di bimbing oleh guru BK untuk pengoptimalan potensi serta membantu kesulitan anak tersebut denganbekerja sama dengan guru dan orang tua akan lebih cenderung menurunkan persentase anak mengalami kesulitan dalam menulis ( Mardika, 2017)

\section{Penanganan Kesulitan Menulis (Remedial Teaching)}

Penanganan kesulitan menulis pada anak yang dapat diupayakan oleh guru bimbingan dan konseling, sebagai berikut: 1) Memberikan anak waktu untuk belajar menulis lebih banyak daripada biasanya. 2) Menempatkan anak dalam suasana kehidupan yang gemar menulis. guru BK dapat menciptakan kenyamana saat membimbing anak dalam mengentaskan permasalahan menulisnya. 3) Guru BK dapat menyerahkan sepenuhnya kepercayaan atas kata maupun kalimat apapun yang akan ditulis oleh siswa Berikan semua kemampuan yang ada dan mengontrol setiap tulisan yang diusahakan oleh anak. 4) Memberikan motivasi secara berkala agar anak tau apresiasi setiap hal yang dicapainya semakin bagus menulis akan semakin baik dalam bentuk pengekspresiannya. (Mardika, 2017)

Adapun alternatif lain dalam pemecahan yang mungkin untuk ditempuh adalah sebagai berikut: 1) Siswa harus sering diberi motivasi belajar baik oleh guru bimbingan dan konseling, walikelas maupun orang tuanya, 2) Siswa diberikan buku bacaan sehingga siswa tetap berlatih untuk menulis dengan dimunculkan huruf-huruf yang jarang ditemui seperti F, f, Q, q, X, x, Z, z. 3) Diberikan motivasi agar anak selalu bersemangat dalam membaca. 4) Guru bimbingan dan konseling dan guru mata pelajaran harus mampu melakukan pendekatan kepada anak. 5) Siswa harus banyak latihan menulis ( Irmayani, 2016)

\section{Peran Bimbingan dan Konseling}

Bimbingan dan Konseling merupakan salah satu unsur terpadu dalam keseluruhan program pendidikan dilingkungan sekolah. Tugas guru bimbingan dan konseling di uraikan oleh Salahuddin (2010) diantaranya adalah Kegiatan melaksanakan dalam pelayanan bimbingan pribadi, bimbingan sosial, bimbingan belajar, bimbingan karir, serta semua jenis layanan termasuk kegiatan pendukung yang dihargai sebanyak 6 jam. Kemudian menyelenggarakan bimbingan terhadap siswa, baik yang bersifat preventif, persetif maupun yang bersifat korektif atau kuratif.Guru mata pelajaran, guru bimbingan dan konseling atau konselor yang membimbing 150 orang siswa dihargai sebanyak 18 jam.

Berdasarkan uraian di atas, dapat di simpulkan bahwa peranan guru bimbingan dan konseling sangat penting keberadaannya sebagai penunjang salah satu proses belajar dan termasuk penyesuain diri siswa. 


\section{KESIMPULAN}

Disgrafia merupakan kesulitan khusus anak - anak yang tidak bisa menuliskan atau mengekspresikan pikirannya kedalam bentuk tulisan, tidak bisa karena mereka tidak mampu menyusun kata dengan baik dan mengkoordinasikan motorik halusnya (tangan) untuk menulis. pada anak - anak umumnya kesulitan terjadi pada saat anak mulai belajar menulis. Adapun alternatif lain dalam pemecahan yang mungkin untuk ditempuh adalah sebagai berikut, Siswa harus sering diberi motivasi belajar baik oleh guru maupun orang tuanya dengan bersabar, Siswa diberi buku bacaan yang menarik dan di dalam buku tersebut terdapat frekuensi yang sering memunculkan huruf-huruf yang jarang ditemui seperti F, f, Q, q, X, x, Z, Z., Diberi motivasi gemar membaca karena dengan banyak membaca akan bertambah penguasaan hurufnya, Guru maupun orang tuanya harus memberi stimulus agar siswa dapat berani berbicara dan mendapatkan jati dirinya, Siswa harus banyak latihan menulis.Adanya program bimbingan dan konseling ini guru BK dapat memberikan solusi-solusi yang telah diuraian di atas terhadap keslitan belajar yang di alami siswa terkhusus pada siswa yang kesulitan dalam hal menulis.

\section{REFERENSI}

Irmayani,2016. Analisis Kesulitan Belajar Menulis pada Siswa Kelas III Sekolah Dasar Negeri 1 Rantau Selamat Kec. Rantau Selamat KabAceh Timur

Kharizmi, Muhammad. 2019. Kesulitan Siswa Sekolah Dasar dalam Meningkatkan Kemampuan Literasi. Jurnal Pendidikan Almuslim. Vol VII No.2.

Mardika, Tiwi. 2017. Analisis Faktor-faktor Kesulitan Membaca Menulis dan Berhitung Siswa Kelas 1 SD. Dinamika Pendidikan dasar.Vol 1 No 1.

Mulyati, 2012.Mengatasi KesulitaN Belajar Menulis ( Disgrafia) Melalu Metode Bingkai Bagi Anak Tuna Grahita Kelas II SDLB di Skb. Madina Serang.Serang ; SDLB.

Prayitno. 2004. Dasar-dasar Bimbingan dan Konseling. Jakarta: Rineka Cipta.

Salahudin, Anas. 2010. Bimbingan dan Konseling. Cet.1. Bandung. Pustaka Setia.

Suhartono, 2016.Pembelajaran Menulis Untuk Anak Disgrafia di Sekolah Dasar.Vol 12 No. 1 Maret 2016.

Yarni, Gusti. 2018. Meningkatkan Kemampuan Menulis Kreatif Siswa Melalui Pendekatan Whole Langue dengan Teknik Menulis Jurnal. Jakarta: UNJ PGSD. 